\title{
PENDAMPINGAN IBU HAMIL DI ERA PANDEMI COVID-19 DALAM UPAYA PENINGKATAN CAKUPAN PELAYANAN IBU HAMIL DI PUSKESMAS KARYA MULIA PONTIANAK
}

\author{
Eka Riana1), Tria Susanti' ${ }^{1)}$, Nadhea Rizha Ananda1), Rizka Anisa1) \\ ${ }^{1)}$ Program Studi DIII Kebidanan, Politeknik ‘Aisyiyah Pontianak, Pontianak, Kalimantan Barat, Indonesia \\ Corresponding author : Eka Riana \\ Email : ekariana8@gmail.com
}

Diterima 11 Januari 2021, Direvisi 01 Maret 2021, Disetujui 08 Maret 2021

\begin{abstract}
ABSTRAK
Kesehatan Ibu dan Anak merupakan salah satu masalah penting pencapaian pembangunan kesehatan dunia. Saat ini di Indonesia tidak terkecuali Kalimantan Barat sedang menghadapi masa pandemi Covid19 , yaitu penyakit yang disebabkan oleh jenis coronavirus baru yaitu Sars-CoV-2. Angka kematian ibu melahirkan di Kota Pontianak meningkat sebagai dampak pandemi covid-19. Juni Tahun 2020 tercatat 7 ibu melahirkan yang meninggal. Jumlah ini meningkat dari tahun lalu yang hanya 5 ibu yang meninggal. Proporsi pemeriksaan kehamilan (KI) di Kalimantan Barat masih rendah yaitu sebesar 79,35 $\%$ dan untuk wilayah Kota Pontianak sebesar $88,89 \%$. Sedangkan proporsi pemeriksaan kehamilan (K4) di Kalimantan Barat sebesar 65,13\% dan untuk Kota Pontianak 74,45\% (Kemenkes RI, 2018). Berdasarkan hasil wawancara kepada 10 ibu hamil, 8 diantaranya menjawab takut dan was-was untuk melakukan pemeriksaan kehamilan di Puskesmas (PWS KIA PKM Karya Mulia, 2020). Tujuan Pengabdian ini untuk meningkatkan pengetahuan ibu hamil tentang pentingnya pemeriksaan kehamilan di masa Pandemi Covid-19 dan peningkatan peran kader kesehatan dalam melakukan pendampingan pada ibu hamil. Metode yang digunakan yaitu pre-test dan post-test sebelum pelaksanaan penyuluhan kepada ibu hamil dan kader kesehatan kemudian pemutaran video tutorial pemeriksaan kehamilan di masa pandemi covid-19 dan pembagian poster edukasi pentingnya pendampingan ibu hamil. Hasil kegiatan ini mendapat respon yang baik dari peserta serta terdapat peningkatan pengetahuan dari sebelum mendapatkan penyuluhan dengan setelah mendapat penyuluhan tentang pemeriksaan kehamilan di masa pandemi covid-19 dan Peran kader pendamping Ibu hamil di masa Pandemi Covid19.
\end{abstract}

Kata Kunci: ibu hamil; pandemi covid-19; kader kesehatan

\begin{abstract}
Mother and child health is one of the important issues in achieving world health development. Currently in Indonesia, including West Kalimantan, is facing the Covid-19 pandemi, this is a disease caused by a new type of coronavirus, namely Sars-CoV-2. The maternal mortality rate in Pontianak city has increased as a result of the Covid-19 pandemi. In June 2020, there were seven mothers died after giving birth. This number increased from last year when only five mothers died after giving birth. The proportion of antenatal care $(\mathrm{KI})$ in West Kalimantan was still low, namely $79.35 \%$ for Pontianak city about $88.89 \%$. While the proportion of antenatal care (K4) in West Kalimantan was $65.13 \%$ and for Pontianak city was $74.45 \%$ (Kemenkes RI, 2018). Based on the results of interviews with ten pregnant women, eight of them answered felt fear and anxiety to carry out pregnancy checks at the Puskesmas (PWSKIA PKM Karya Mulia, 2020). To increase the knowledge for pregnant women about the importance of antenatal care during the Covid-19 and to increase the role of health cadres in assisting pregnant women. The method used pre-test and post-test before implementing counseling to pregnant women and health cadres, then watching a tutorial video about monitoring of pregnancy and Medical examinations during the Covid-19 and distributing educational posters on the importance of assisting pregnant women. This activity received a good response from the participants and their knowledge has increased from before getting counseling and after receiving counseling about pregnancy checks during the Covid-19 and the role of cadres in assisting pregnant women during the Covid- 19.
\end{abstract}

Keywords: pregnant women; covid-19 pandemi; health cadres.

\section{PENDAHULUAN}

Kesehatan Ibu dan Anak merupakan

salah satu masalah penting pencapaian pembangunan kesehatan dunia. Pencapaian program KIA dapat dilihat dari Laporan Pemantauan Wilayah Setempat (PWS) KIA 
yang pencatatannya bulanan yang merupakan hal yang sangat penting, karena hasil laporan tersebut dapat dijadikan tolak ukur dalam menilai pengendalian masalah kesehatan di seluruh wilayah kabupaten atau kota.

Program Kesehatan Ibu dan Anak (KIA) merupakan salah satu program wajib di Puskesmas. Perhatian khusus harus diberikan terhadap kesehatan ibu, bayi baru lahir, bayi dan balita. Hal ini karena ibu, bayi dan balita termasuk dalam penduduk yang rentan terhadap penyakit. Selain itu, Angka Kematian Ibu (AKI), Angkat Kematian Bayi (AKB) dan Angka Kematian Balita (AKABA) merupakan salah satu indikator derajat kesehatan suatu negara. Kegiatan pokok Program Kesehatan Ibu dan Anak (KIA) yang meliputi pelayanan antenatal, pelayanan pertolongan persalinan, deteksi dini ibu hamil beresiko, penanganan komplikasi kebidanan, pelayanan kesehatan neonatal dan ibu nifas (Depkes RI, 2010).

Berdasarkan Riskesdas (2018) proporsi pemeriksaan kehamilan (KI) di Indonesia masih cukup rendah yaitu sebesar $86 \%$, proporsi pemeriksaan kehamilan di Kalimantan barat sebesar 79,35 \% lebih rendah dari proporsi nasional dan untuk wilayah Kota Pontianak sebesar 88,89\%. Sedangkan proporsi pemeriksaan kehamilan (K4) secara nasional yaitu $74,1 \%$, di Kalimantan Barat sebesar $65,13 \%$ d an untuk Kota Pontianak 74,45\% (Kemenkes RI, 2018).

Saat ini di Indonesia tidak terkecuali Kalimantan Barat sedang menghadapi masa pandemi Covid-19, yaitu penyakit yang disebabkan oleh jenis coronavirus baru yaitu Sars-CoV-2. Angka kematian ibu melahirkan di Kota Pontianak meningkat sebagai dampak pandemi covid-19. Hingga Juni Tahun 2020 saat ini telah tercatat 7 ibu melahirkan yang meninggal. Jumlah ini meningkat dari tahun lalu yang hanya 5 ibu yang meninggal. Peningkatan kematian ibu ini merupakan dampak pandemi covid-19 sehingga aktifitas pelayanan kesehatan sangat terganggu (Antara News, 2020).

Pemeriksaan kehamilan di masa pandemi tentu akan mengalami kendala, akan tetapi pemeriksaan kehamilan dapat dilakukan selama ibu hamil dan petugas kesehatan menerapkan protokol kesehatan Covid-19 selama asuhan (Pitale, 2020).

Terjadinya peningkatan Angka kematian ibu melahirkan di Kota Pontianak. Hingga Juni Tahun 2020 saat ini telah tercatat 7 ibu melahirkan yang meninggal. Jumlah ini meningkat dari tahun lalu yang hanya 5 ibu yang meninggal (Antara News. 22 juni 2020). Peningkatan kematian ibu ini merupakan dampak pandemi covid-19 sehingga aktifitas pelayanan kesehatan sangat terganggu.

Puskesmas Karya mulia merupakan salah satu puskesma yang berada di Kota Pontianak, dimana dari Januari-Juli 2020 terjadi penurunan cakupan pemeriksaan kehamilan. Dari $21 \mathrm{RW}$ yang termasuk wilayah kerja Puskesmas Karya Mulia, terdapat 14 RW yang cakupan $\mathrm{KI}$ nya rendah dibawah target cakupan puskesmas yaitu sebesar $66,7 \%$. Sedangkan untuk cakupan K4 seluruh RW masih di bawah target puskesmas. Hal ini merupakan dampak dari Pandemi covid-19 dimana berdasarkan hasil wawancara kepada $10 \mathrm{ibu}$ hamil, 8 diantaranya menjawab takut dan was-was untuk melakukan pemeriksaan kehamilan di Puskesmas (PWSKIA PKM Karya Mulia, 2020).

Berdasarkan latar belakang di atas maka rumusan masalah yang didapat "Bagaimanakah Pendampingan Ibu Hamil Di Era Pandemi Covid-19 Dalam Upaya Peningkatan Cakupan Pelayanan Ibu Hamil Di Puskesmas Karya Mulia Pontianak Tahun 2020".

\section{METODE}

Metode yang digunakan pada pengabdian masyarakat ini yaitu berbasis webinar melalui media online google meet, live Instagram dan whatsapp group kepada ibu hamil dan kader kesehatan, serta pembagian poster edukasi kepada kader di 4 Posyandu di Wilayah Kerja Puskemas Karya Mulia Kota Pontianak. Kegiatan ini dilaksanakan pada tanggal 2-5 Oktober 2020. Sasaran dalam kegiatan ini adalah Seluruh Ibu hamil dan Kader Posyandu di Wilayah Kerja Puskesmas Karya Mulia. Jumlah ibu hamil yang mengikuti kegiatan sebanyak 17 orang dan kader sebanyak 10 orang. Adapun tahapan yang dilakukan dalam melaksanakan kegiatan ini sebagai berikut :

1. Persiapan kegiatan : menentukan waktu yang tepat untuk memberikan penyuluhan kesehatan dengan ibu hamil dan kader posyandu; mempersiapkan materi yang akan disampaikan dan memastikan jaringan stabil selama kegiatan berlangsung.

2. Membagikan link pretest via whatsapp group kepada peserta.

3. Menyampaikan materi melalui Penyuluhan Kesehatan dan pemutaran video edukasi tentang pemeriksaan kehamilan di masa pandemi covid-19 dan peran kader selama masa pandemi covid -19 .

4. Melakukan feedback (diskusi dan tanya jawab) terkait materi yang telah disampaikan.

5. Membagikan link posttest via whatsapp grup kepada peserta sebagai evaluasi kegiatan. 


\section{HASIL DAN PEMBAHASAN}

Hasil

Kegiatan Penyuluhan kepada ibu hamil tentang Pemeriksaan kehamilan di masa pandemi covid-19 diakhiri dengan Pemutaran video edukasi pemeriksaan kehamilan di masa pandemi covid-19 diikuti secara antusias oleh ibu hamil. adapun jumlah peserta yang mengikuti penyuluhan sebanyak 17 ibu hamil dan Penyuluhan "Peran kader Pendamping Ibu hamil di masa Pandemi Covid-19 diikuti sebanyak 10 kader dari 14 kader posyandu yang ada di Wilayah Kerja Puskesmas Karya Mulia.

Hasil Pre dan Post Test Penyuluhan Pentingnya Pemeriksaan Kehamilan di masa Pandemi Covid-19 sebagai berikut :

1) Pre test Penyuluhan pentingnya pemeriksaan kehamilan di masa Pandemi Covid-19

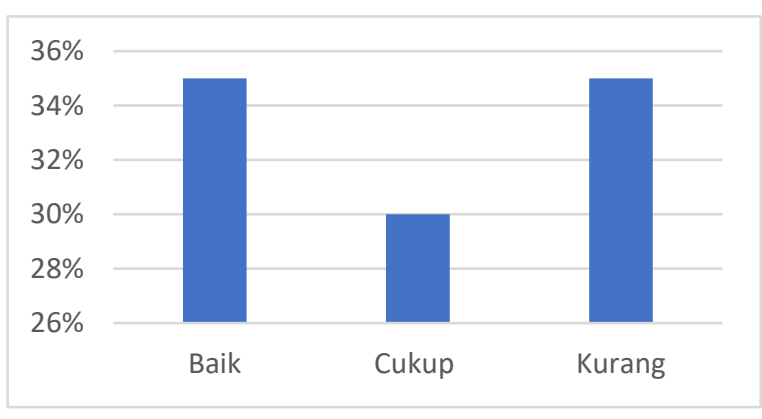

Gambar 1. Hasil Pretest ibu hamil dalam pentingnya pemeriksaan kehamilan

Hasil pretest ibu hamil dalam pentingnya pemeriksaan kehamilan menunjukan bahwa pengetahuan terkait peran ibu hamil baik dalam melakukan pemeriksaan kehamilan yaitu sebanyak 6 orang (35\%) sedangkan (35\%) 6 orang dari ibu hamil memiliki pengetahuan yang kurang terhadap pentingnya pemeriksaan kehamilan.

2) Post test Penyuluhan pentingnya pemeriksaan kehamilan di masa Pandemi Covid-19

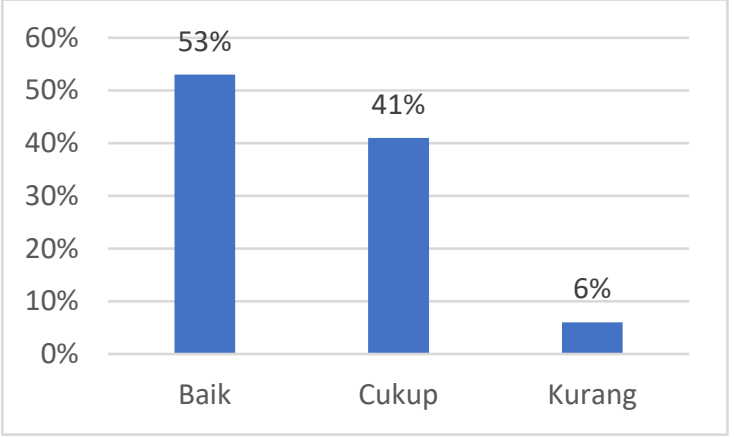

Gambar 2. Hasil Posttest ibu hamil dalam pentingnya pemeriksaan kehamilan
Hasil posttest menunjukan bahwa pengetahuan ibu hamil terkait peran serta dalam melakukan pemeriksaan kehamilan yaitu berkategori baik sebanyak 9 orang (53\%).

Hasil Pre dan Post test Penyuluhan Peran Kader Pendamping lbu hamil di masa Pandemi Covid-19 sebagai berikut:

1) Pre test Penyuluhan Peran kader Pendamping Ibu hamil di masa Pandemi Covid-19

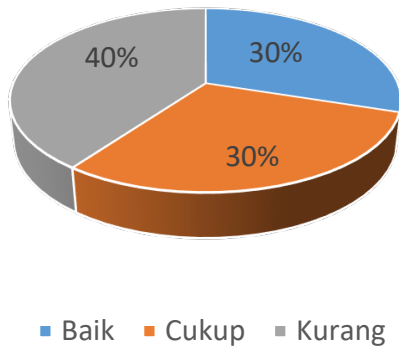

Gambar 3. Hasil Pretest peran kader pendamping ibu hamil di masa Pandemi covid-19

Hasil pretest menunjukan bahwa peran kader dalam mendampingi ibu hamil dimasa pandemi covid-19 berkategori kurang yaitu sebanyak 4 orang $(40 \%)$.

2) Post test Penyuluhan Peran kader Pendamping lbu hamil di masa Pandemi Covid-19

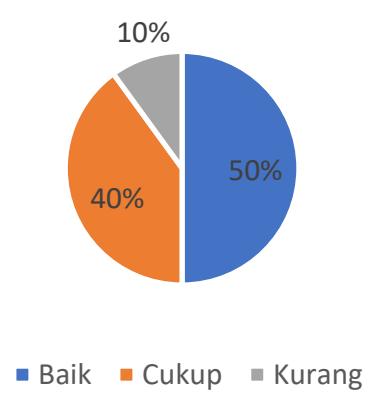

Gambar 4. Hasil Posttest peran kader pendamping ibu hamil di masa pandemi covid-19

Hasil posttest menunjukan bahwa peran kader dalam mendampingi ibu hamil dimasa pandemi covid-19 berkategori kurang terjadi penurunan yaitu 1 orang $(10 \%)$. 


\section{Pembagian Poster Edukasi}

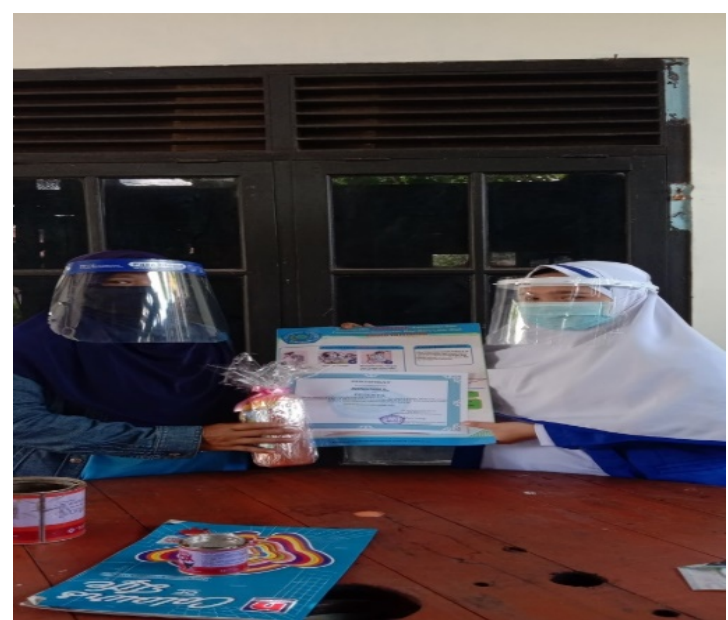

Gambar 5. Pembagian Poster Edukasi

Pembagian poster edukasi dilakukan sebagai kegiatan tambahan dalam upaya meningkatkan pengetahuan kader dan sebagai bahan informasi untuk anggota kader posyandu yang lainnya. Poster diberikan kepada seluruh kader posyandu yang ada di wilayah puskesmas karya mulia yaitu sebanyak 14 posyandu.

Pembagian poster dilaksanakan pada tanggal 4 Oktober 2020 dengan tetap menerapkan protokol kesehatan yaitu mencuci tangan, menggunakan masker, menjaga jarak dan menggunakan face shield.

\section{Pembahasan}

Kehamilan dan persalinan merupakan proses alamiah (normal) dan bukan proses patologis, tetapi kondisi normal dapat menjadi patologi/abnormal apabila tidak di pantau dengan baik. Tujuan asuhan kehamilan yang harus diupayakan oleh bidan melalui asuhan antenatal yang efektif; adalah mempromosikan dan menjaga kesehatan fisik mental sosial ibu dan bayi dengan pendidikan kesehatan, gizi, kebersihan diri, dan proses kelahiran bayi. Akan tetapi, diawal tahun 2020 dunia termasuk Indonesia khususnya di Kalimantan barat menghadapi keadaan dimana seluruh kegiatan termasuk pelayanan kesehatan terbatas, yakni terjadinya Pandemi Covid-19. Pemeriksaan kehamilan di masa pandemi tentu akan mengalami kendala, akan tetapi pemeriksaan kehamilan dapat dilakukan selama ibu hamil dan petugas kesehatan menerapkan protokol kesehatan Covid-19 selama asuhan (Pitale, 2020).

Penyuluhan yang dilakukan kepada ibu hamil dan kader posyandu bertujuan meningkatkan pengetahuan ibu hamil dan kader posyandu tentang kehamilan dan pemeriksaan kehamilan khususnya di masa pandemi covid-19. Pengetahuan adalah hasil dari tahu, ini didapat setelah seorang melakukan pengindraan terhadap objek tertentu. Pengindraan dapat dilakukan dengan panca indra manusia, yakni indra penglihatan, penciuman, pendengaran, perabaan, pengecapan dan rasa. Media promosi merupakan alat bantu untuk meyampaikan pendidikan kesehatan yang bekerja untuk menstimulasi panca indra. Dalam pelaksanaan penyuluhan yang dilakukan, berdasarkan hasil pre test dan post test, terjadi peningkatan pengetahuan ibu hamil dan ibu kader sebelum dan setelah diberikan penyuluhan. Hal ini sesuai dengan penelitian yang dilakukan oleh aritonang, dkk (2020) yakni setelah dilakukan penyuluhan adalah adanya peningkatan pemahaman ibu hamil tentang COVID-19 dan penurunan kecemasan ibu hamil selama kehamilan di era pandemi COVID-19.

Ibu hamil tercatat salah satu kelompok rentan resiko terinfeksi COVID-19 dikarenakan pada masa kehamilan terjadinya perubahan fisiologi yang mengakibatkan penurunan kekebalan parsial dan dapat menyebabkan dampak yang serius bagi ibu hamil (Aritonang, J., dkk. 2020). Kecemasan sering dialami ibu hamil Ketika akan melakukan pemeriksaan kehamilan di fasilitas kesehatan. Hal ini berdampak pada menurunnya jumlah kunjungan (K1 dan K4) di Puskesmas Karya Mulia. Akan tetapi ada beberapa hal yang dapat dilakukan ibu hamil dimasa pandemi yaitu Ibu hamil diminta mempelajari buku KIA untuk diterapkan dalam kehidupan sehari-hari termasuk mengenali tanda bahaya pada kehamilan. Jika ada keluhan atau tanda bahaya, ibu hamil harus segera memeriksakan diri ke fasyankes. Apabila akan melakukan pemeriksaan kehamilan di Fasyankes, maka harus menerapkan protocol kesehatan yang ketat dan diharapkan menghubungi bidan di pelayanan kesehatan terlebih dahulu.

Posyandu (Pos Pelayanan Terpadu) merupakan bentuk pemberdayaan masyarakat yang bertujuan untuk meningkatkan kesehatan ibu dan anak pada level dasar oleh kader. Tujuan utamanya adalah memberikan kemudahan masyarakat dalam akses pelayanan kesehatan bagi ibu, bayi dan anak balita. Pada masa pandemi pelayanan posyandu menjadi kurang optimal . kader dan pembina posyandu harus lebih kreatif dalam memberikan pelayanan karena pada masa pandemi kehadiran masyarakat sangat menurun. Dengan demikian diperlukan kreatifitas pelayanan yang berbasis teknologi informasi sehingga pemantauan dan pelayanan kesehatan dapat terus dilakukan misalnya melalui daring, grup whatsapp, kunjungan 
rumah dan lain-lain (Arsyati, A. 2020 \& Juwita, D.R, 2020).

\section{SIMPULAN DAN SARAN \\ Simpulan}

Dari kegiatan pengabdian masyarakat yang telah dilakukan dapat disimpulkan bahwa ada peningkatan pengetahuan ibu hamil tentang pemeriksaan kehamilan di masa Pandemi Covid-19 dan ada peningkatan pengetahuan kader kesehatan tentang pendampingan ibu hamil di masa Pandemi Covid-19 dengan harapan dapat meningkatkan jumlah cakupan pemeriksaan kehamilan di Puskesmas Karya Mulia Kota Pontianak.

\section{Saran}

Pihak Puskesmas, Kader Kesehatan maupun Masyarakat di Wilayah Kerja Puskesmas Karya Mulia dapat bekerja sama dalam upaya meningkatkan Kesehatan Ibu dan Anak di Era Pandemi Covid-19 salah satunya dengan memotivasi ibu hamil untuk tetap melakukan kunjungan antenatal dimasa pandemi serta keikutsertaan keluarga dalam berpartisipasi membawa ibu hamil untuk melakukan kunjungan antenatal sesuai standar yaitu minimal 4 kali kunjungan selama kehamilan.

\section{UCAPAN TERIMAKASIH}

Tim penulis menyampaikan terimakasih kepada semua pihak yang telah membantu dalam pelaksanaan kegiatan Pengabdian Masyarakat ini. Secara khusus penulis ingin mengucapkan terimakasih dan penghargaan yang setinggi-tingginya kepada:

1. Ibu Tilawaty Aprina, SST., M.Kes selaku Direktur Politeknik 'Aisyiyah Pontianak.

2. Ibu Ismaulidia Nurvembrianti, SST., M.Keb selaku Ketua Program Studi DIII Kebidanan Politeknik 'Aisyiyah Pontianak.

3. Kepala Puskesmas Karya Mulia Kota Pontianak.

4. Bidan Koordinator dan Kader Posyandu Puskesmas Karya Mulia Kota Pontianak.

5. Ibu hamil dan Kader Kesehatan di Wilayah Kerja Puskesmas Karya Mulia Kota Pontianak.

6. Rekan kerja yang telah membantu terlaksananya kegiatan ini.

\section{DAFTAR RUJUKAN}

Antara News. (2020). Angka kematian ibu melahirkan di Kota Pontianak meningkat.

Aritonang, J., Nugraeny, L., Sumiatik, Siregar, R.N. (2020). Peningkatan Pemahaman Kesehatan pada Ibu Hamil dalam Upaya Pencegahan COVID-19 Jurnal Solma, 09(2), 261-269. Doi: http://dx.doi.org/10.22236/solma.v9i2.5 522

Arsyati, A.M., Chandra, V.K (2020) Assesment Kesiapan Kader Posyandu Dalam Pelatihan Penggunaan Media Online. jurnal hearty. Vol.8 No.1, 2020 Agustus- February, hlm. 27 - 32

Direktorat Kesehatan Keluarga. (2020). Pedoman Bagi Ibu Hamil, Ibu Nifas, dan Bayi Baru Lahir Di Era Pandemi Covid-19. 9-12. http://www.kesga.kemkes.go.id/images /pedoman/Pedoman bagi lbu Hamil, Bersalin, Nifas dan BBL di Era Pandemi COVID 19.pdf

Juwita, D.R (2020). Makna Posyandu Sebagai Sarana Pembelajaran Non Formal Di Masa Pandemi Covid 19. Jurnal Meretas. Volume 7 Nomor 1

Kemenkes RI. (2018). Hasil Provinsi Utama Riskesdas 2018 kalimantan Barat. Hasil Provinsi Utama Riskesdas, 2021.

http://www.depkes.go.id/resources/do wnload/infoterkini/materi_rakorpop_2018/Hasil Riskesdas 2018.pdf

Permenkes RI No.97. (2014). PERATURAN MENTERI KESEHATAN REPUBLIK INDONESIA NOMOR 97 TAHUN 2014. Menkes.RI.

Pitale, D. L. (2020). Antenatal care during the COVID-19 pandemi. 9(10), 4052-4056.

Prasetyaningsih. (2018). Hubungan Umur, Pengetahuan dan Dukungan Keluarga dengan Kunjungan Antenatal Care (ANC) (K4) lbu Hamil di Puskesmas Pariaman Tahun 2018. Jurnal IImu Keperawatan Dan Kebidanan, 11(1), 62-69.

PWSKIA PKM Karya Mulia. (2020). PWSKIA PUSKESMAS KARYA MULIA.

Tyastuti, S., \& Wayuningsih, H. P. (2016). Modul Bahan Ajar Cetak Asuhan Kebidanan Kehamilan. BPSDM Kemenkes RI. 